\title{
Inhibition of Herpesvirus-6B RNA Replication by Short Interference RNAs
}

\author{
Jong-Sub Yoon, Sun-Hwa Kim, Min-Chul Shin, Dong-Gun Lee”, Seong-Karp Hong, Yong-Tae Jung*, \\ In-Gu Khang', Wan-Shik Shin ${ }^{\dagger}$, Chun-Choo Kim ${ }^{\dagger}$ and Soon-Young Paik* \\ Department of Microbiology, and Department of Internal Medicine, \\ College of Medicine, The Catholic University of Korea, Seoul 137-701, Korea \\ ${ }^{ \pm}$Department of Microbiology, College of Advanced Science, Dankook University, Seoul 140-714, Korea
}

Received 6 August 2003, Accepted 15 August 2003

\begin{abstract}
RNA interference (RNAi) is a process of sequence-specific gene silencing, which is initiated by double-stranded RNA (dsRNA). RNAi may also serve as an antiviral system in vertebrates. This study describes the inhibition of herpesvirus-6B (HHV-6B) replication by short interference RNAs (siRNAs) that are targeted to the U38 sequence that encodes DNA polymerase. When virusinfected SupT1 cells were treated by siRNA, these cells blocked the cytopathic effect (CPE) and detected the HHV6B antibody-negative in indirect immunofluorescence assays (IFA). Our result suggests that RNAi can efficiently block Herpesvirus-6B replication.
\end{abstract}

Keywords: Herpes virus 6B, RNA interference, SupT1 cells

\section{Introduction}

Post-transcriptional gene silencing by double-stranded RNA (dsRNA), or RNA interference (RNAi), is a new tool for investigating gene functions in an increasing number of organisms (Fire et al., 1998). RNAi was first discovered in plants, worms, and other model organisms, but more recently RNAi was also reported in various mammalian cells (Svoboda et al., 2000).

Long double-stranded RNAs are processed into 21- to 23nucleotide (nt) small interfering RNAs (siRNAs) by the Dicer enzyme and then incorporated into a multicomponent nuclease, called the RNA-induced silencing complex (Hannon, 2002).

When activated, this complex can specifically down regulate the gene expression. RNAi has been used to examine the gene function of multiple model organisms, including

*To whom correspondence should be addressed.

Tel: 82-2-590-1217; Fax: 82-2-535-6473

E-mail: paik@catholic.ac.kr flies, trypanosomes, zebra fish, mice, and plants (Jia and Sun, 2003).

However, in most mammalian cells, double-stranded RNAs that are longer than $30 \mathrm{nt}$ activate an interferon response, leading to nonspecific degradation of RNA transcripts and a general shutdown of host cell protein translation (Baglioni and Nilsen, 1983). This nonspecific effect can be circumvented by using synthetic siRNAs that are $21 \mathrm{nt}$ long with short $3^{\prime}$ overhangs (Elbashir et al., 2001). The synthesized siRNAs induce the homology-dependent degradation of cognate mRNA and have been used to knock down the expression of endogenous and heterologous genes in mammalian cell lines (Caplen et al., 2001). Although there is evidence suggesting that viruses have evolved proteins that suppress RNA silencing, RNAi is believed to have evolved as a host defense mechanism against transposable elements and infectious viruses (Li and Ding, 2001). Several studies demonstrated that virus infection can be prevented by pretreatment or cotreatment with siRNAs. However, no study has reported that cells or tissues already infected with a virus can be cured (Andino, 2003).

HHV-6 is recognized as an important pathogen in diseases such as meningoencephalitis, infectious mononucleosis, lymphoproliferative disease, chronic fatigue syndrome, Kikuchi-Fujimoto's disease, multiple sclerosis, AIDS, and the suppressed marrow function after hematopoietic stem cell transplant (HSCT) (Cone et al., 1999; Doniger et al., 1999). In this study, we investigated whether or not RNAi can be directed to inhibit the replication of herpes virus 6B (HHV6B) that is isolated from Korean hematopoietic stem cell transplant (HSCT) recipients (Lee et al., 2003, in press). We report here that RNAi is an efficient approach for suppressing HHV-6B replication.

\section{Materials and Methods}

Cell culture T-lymphoblastoids ( $\operatorname{SupT}_{1}$ cells) were grown at $37^{\circ} \mathrm{C}$ 
(A)

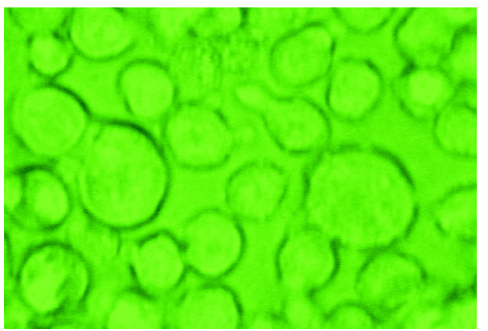

(B)

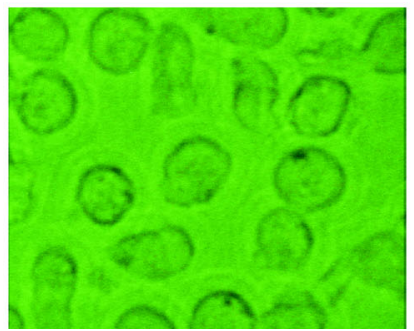

(C)

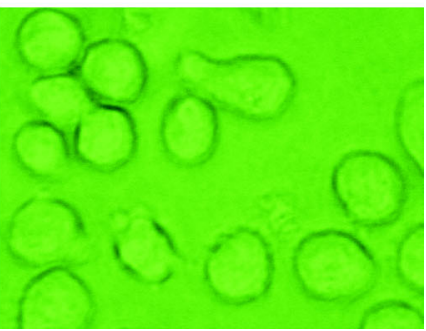

Fig. 1. Inhibition effect of siRNA by morphologenesis in the infected $S_{u p} T_{1}$ cells. The infected SupT1 cells were mock-transfected (A) with RNA duplexes (U38A) (B), or with RNA duplexes (U38B) (C).

(A)

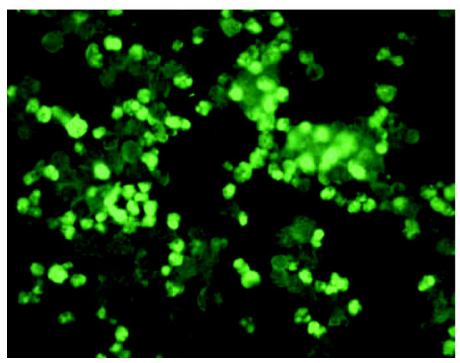

(B)

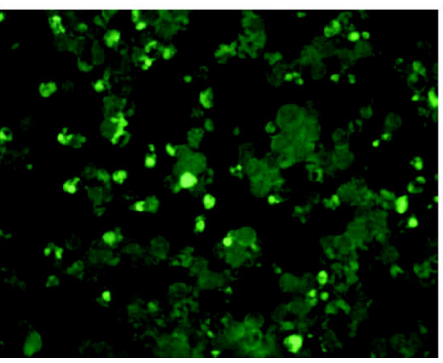

(C)

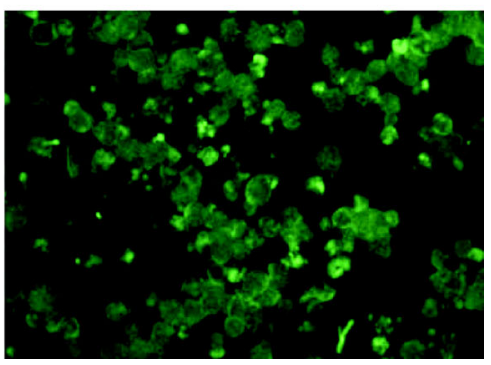

Fig. 2. The siRNA mediate inhibition detected by IFA. Normal, infected cells (A). HHV-6B replication inhibited by siRNA (U38A) (B). HHV-6B replication inhibited by siRNA (U38B) (C). Most of the siRNA-treated cells were HHV-6B antibody-negative in IFA.

under a $5 \% \mathrm{CO}_{2}$ atmosphere in Dulbecco's Modified Eagle Medium (Gibco, Grand Island, USA). It was supplemented with $10 \%$ fetal bovine serum, $1 \mathrm{mM}$ sodium bicarbonate, $100 \mu \mathrm{l} / \mathrm{ml}$ streptomycin, $100 \mathrm{U} / \mathrm{ml}$ penicillin, and $0.29 \mu \mathrm{l} / \mathrm{ml} \mathrm{L-glutamine.}$

Virus culture The cell-free herpesvirus-6B was obtained from a previous study (Lee et al., 2003) and used to infect the fresh $\operatorname{SupT}_{1}$ cells. Uninfected $\operatorname{SupT}_{1}$ cells $\left(1.0 \times 10^{6} / \mathrm{ml}\right)$ were first incubated at $37^{\circ} \mathrm{C}$ for $2 \mathrm{~h}$ with the cell-free virus at a minimal volume (1-2 ml). The culture was then fed with 5\% FBS/RPMI 1640. The cells were incubated until most of the cells showed extensive cytopathic effects (CPE). The cells were then freeze-thawed three times and spun down to remove the cell debris. The cell-free supernatant was used for pelleting by ultra-centrifugation at 25,000 rpm for $60 \mathrm{~min}$. The pelleted virus was concentrated (typically 300-500-fold).

Design of siRNA Two siRNAs were designed to target U38 (DNA polymerase). All of these siRNA sequences start with UU and have approximately $40 \%$ GC contents in their targeting sequences. The selected siRNA targeting sequences were then subjected to a BLAST search against the non-redundant nucleotide sequences in order to ensure that only the intended viral genes were targeted. They were as follows: siRNA-U38A (sense; 5'-AGC AGA UCG AGU UAC AUU CUU-3' and anti-sense; 5'-GAA UGU AAC UCG AUC UGC UUU-3') and siRNA-U38B (sense; 5'-UGU UUA CGA UUC GAU CGA UU-3' and anti-sense; 5'-UCG AUC GAA UCC GUA AAC AUU-3'). All of the siRNAs were purchased from Genotech (Daejeon, Korea). All of the siRNAs were purchased from Genotech (Daejeon, Korea). The siRNAs were prepared according to the manufacturer's recommendations.
siRNA assay The SupT $T_{1}$ cells $\left(1.0 \times 10^{6} / \mathrm{ml}\right)$ were infected with HHV-6B (Kim et al., 2002). After $2 \mathrm{~h}$, we transfected the SupT cells with U38A or U38B in the with or without annealed RNA duplexes $(0.1 \mu \mathrm{M})$ using an oligofectamine reagent (Invitrogen, San Diego, USA). We then observed the morphologic change by light microscopy.

Indirect immunofluorescence assays (IFA) The cells were collected from each well and washed with phosphate buffer saline (PBS). They were centrifuged at 1,200 rpm for $4 \mathrm{~min}$, and then the supernatants were discarded. The cells were resuspended in $200 \mu \mathrm{l}$ PBS and smeared onto Teflon-coated slides. The slides were dried at room temperature and cell fixed with absolute methanol at $-20^{\circ} \mathrm{C}$ for $10 \mathrm{~min}$. After rehydration in PBS for $5 \mathrm{~min}$, the cells were incubated with specific monoclonal antibodies against HHV-6B (Chemicon, Temecula, USA) at $37^{\circ} \mathrm{C}$ for $1 \mathrm{~h}$ in a humidified chamber. The cells were then washed three times with PBS and incubated with fluorescent isothiocyanate (FITC)-conjugated goat anti-mouse immunoglobulin $\mathrm{G}(\mathrm{IgG})$ for $45 \mathrm{~min}$. Coverslips were mounted on the glass slides and examined under a fluorescence microscope (Bae and Lee, 2001) (Axiotech 100, Zeiss, Jena, Germany)

\section{Results and Discussion}

In order to determine whether or not the siRNA that is specific to the HHV-6B genome could inhibit HHV-6B replication, the infected $\mathrm{SupT}_{1}$ cells were transfected with or without RNA duplexes (siRNAs). At five days after transfection, the siRNA 
effects were confirmed by the morphologic change that was observed using light microscopy. IFA was performed using a HHV-6B specific monoclonal antibody. The mock-transfected cells became grossly enlarged and multinucleated, while the cells that were treated with siRNA (U38A and U38B) detected no morphologic change (Fig. 1). Fluorescence imaging was used to monitor the HHV-B replication and dissemination level. Mock-transfected cells displayed fluorescence, whereas the cells that were treated with siRNA had significantly reduced fluorescence (Fig. 2). These results suggest that siRNA (U38A and U38B) can inhibit efficiently and specifically the HHV-6B replication in infected cells.

Recently, many viruses have been shown to be susceptible to inhibition by RNAi, suggesting that RNAi plays an adaptive antiviral role in controlling these viral infections ( $\mathrm{Hu}$ et al., 2002). This study is a first step toward demonstrating the inhibition of HHV-6B replication by siRNA. In order to develop siRNA technology into an effective anti HHV-6B therapy, the identification of siRNA with a higher efficacy, greater stability, and targeting of siRNA is necessary.

Acknowledgments This work was supported by a Korea Research Foundation Grant (KRF-2001-005-F20009).

\section{References}

Andino, R. (2003) RNAi puts a lid on virus replication. Nat. Biotechnol. 21, 629-630.

Baglioni, C. and Nilsen, T. W. (1983) Mechanisms of antiviral action of interferon. Interferon. 5, 23-42.

Bae, J. S. and Lee, S. T. (2001) The Human PTK6 interacts with a $23-\mathrm{kDa}$ tyrosine-phosphorylated protein and is localized in cytoplasm in breast carcinoma T-47D cells. J. Biochem. Mol. Biol. 34, 33-38.

Billy, E., Brondani, V., Zhang, H., Muller, U. and Filipowicz, W. (2001) Specific interference with gene expression induced by long, double-stranded RNA in mouse embryonal teratocarcinoma cell lines. Proc. Natl. Acad. Sci. USA 98, 14428-14433.

Caplen, N. J., Parrish, S., Imani, F., Fire, A. and Morgan, R. A. (2001) Specific inhibition of gene expression by small doublestranded RNAs in invertebrate and vertebrate systems. Proc. Natl. Acad. Sci. USA 98, 9742-9747.

Chiu, Y. L. and Rana, T. M. (2002) RNAi in human cells: Basic structural and functional Features of small interfering RNA. Mol. Cell 10, 549-561.

Cone, R. W., Huang, M. L., Corey, L., Zeh, J., Ashley, R. and Bowden, R. (1999) Human herpes virus 6 infection after bone marrow transplantation: clinical and virologic manifestations. $J$. Infect. Dis. 179, 311-318.

Doniger, J., Muralidhar, S. and Rosenthal, L. J. (1999) Human cytomegalovirus and human herpes virus 6 genes that transform and transactivate. Clin. Microbiol. Rev. 12, 367-382.

Elbashir, S. M., Harborth, J., Lendeckel, W., Yalcin, A., Weber, K. and Tuschl, T. (2001) Duplexes of 21-nucleotide RNAs mediate RNA interference in cultured mammalian cells. Nature 411, 494-498.

Fire, A., Xu, S., Montgomery, M. K., Kostas, S. A., Driver, S. E. and Mello, C. C. (1998) Potent and specific genetic interference by double-stranded RNA in Caenorhabditis elegans. Nature 391, 806-811.

Garrus, J. E., von Schwedler, U. K., Pornillos, O. W., Morham, S. G., Zavitz, K. H., Wang, H. E., Wettstein, D. A., Stray, K. M., Cote, M., Rich, R. L., Myszka, D. G. and Sundquist, W. I. (2001) Tsg101 and the vacuolar protein sorting pathway are essential for hiv-1 budding. Cell 107, 55-65.

Hamasaki, K., Nakao, K., Matsumoto, K., Ichikawa, T., Ishikawa, H. and Eguchi, K. (2003) Short interfering RNA-directed inhibition of hepatitis B virus replication. FEBS Lett. 22, 5154.

Hannon, G. J. (2002) RNA interference. Nature 418, 244-251.

Hu, W. Y., Myers, C. P., Kilzer, J. M., Pfaff, S. L. and Bushman, F. D. (2002) Inhibition of retroviral pathogenesis by RNA interference. Curr. Biol. 6, 1301-1311.

Isegawa, Y., Mukai, T., Nakano, K., Kagawa, M., Chen, J., Mori, Y., Sunagawa, T., Kawanishi, K., Sashihara, J., Hata, A., Zou, P., Kosuge, H. and Yamanishi, K. (1999) Comparison of the complete DNA sequences of human herpes virus 6 variants A and B. J. Virol. 73, 8053-8063.

Jia, Q. and Sun, R. (2003) Inhibition of gamma herpesvirus replication by RNA interference. J. Virol. 77, 3301-3306.

Kim, C. H., Park, Y. S., Chung, K. N. and Elwood, P. C. (2002) Sorting and function of the human folate receptor is independent of the caveolin expression in fisher rat thyroid epithelial cells. J. Biochem. Mol. Biol. 35, 395-402.

Kapidia, S. B., Brideau-Anderson, A. and Chisari, F. V. (2003) Interference of hepatitis $\mathrm{C}$ virus RNA replication by short interfering RNAs. Proc. Natl. Acad. Sci. USA 18, 2014-2018.

Lee, D. G., Sang, T. P., Choi, Su, M., Kim, S. H., Choi, J. H., Yoo, J. H., Park, S. W., Lee, G. C., Paik, S. Y., Shin, W. S. and Kim, C. C. (2003) Prevalence of human herpesvirus-6B in Korean hematopoietic stem cell transplantation recipients. Mol. Cells, 16, 307-315.

Li, W. X. and Ding, S. W. (2001) Viral suppressors of RNA silencing. Curr. Opin. Biotechnol. 12, 150-154.

Seo, M. Y., Abrignani, S., Houghton. M. and Han, J. H. (2003) Small interfering RNA-mediated inhibition of hepatitis C virus replication in the human hepatoma cell line Huh-7. J. Virol. 77, 810-812.

Svoboda, P., Stein, P., Hayashi, H. and Schultz, R. M. (2000) Selective reduction of dormant maternal mRNA in mouse oocytes by RNA interference. Development 127, 4147-4156.

Svoboda, P., Stein, P. and Schultz, R. M. (2001) RNAi in mouse oocytes and preimplantation embryos: effectiveness of hairpin dsRNA. Biochem. Biophys. Res. Commun. 287, 1099-1104. 